\title{
Synthetic and Structural Exploration of [24]Tetrathiacalix[2]arene[2]pyrimidines
}

\author{
Mahendra P. Sonawane, Kristof Van Hecke, ${ }^{\dagger, \dagger}$ Jeroen Jacobs, $^{\dagger}$ Joice Thomas, Luc Van Meervelt, ${ }^{\dagger}$ \\ Wim Dehaen,* and Wim Van Rossom ${ }^{\S}$ \\ Molecular Design and Synthesis and ${ }^{\dagger}$ Biomolecular Architecture, Department of Chemistry, Katholieke Universiteit Leuven, \\ Celestijnenlaan 200F, 3001 Leuven, Belgium \\ ${ }^{\ddagger}$ Department of Inorganic and Physical Chemistry, Universiteit Gent, Krijgslaan 281, Building S3, 9000 Gent, Belgium
}

\section{Supporting Information}

ABSTRACT: A novel class of two atom bridged metacyclophanes- $\left[2_{4}\right]$ thiacalix $[2]$ arene[2]pyrimidines-has been synthesized via a straightforward $S_{N} A r$ reaction. The conformational properties and intra-annular dimensions of the $\left[2_{4}\right]$ thiacalix[2] arene[2]pyrimidines were evaluated by X-ray structure analysis and compared with known homothia- and thiacalixarenes. Post-macrocyclization oxidation of the bridging sulfur moieties resulted in a $\left[2_{4}\right]$ sulfonylcalix[2] arene[2]pyrimidine, which gave access to an unexplored cavity size among sulfonylcalixarenes.

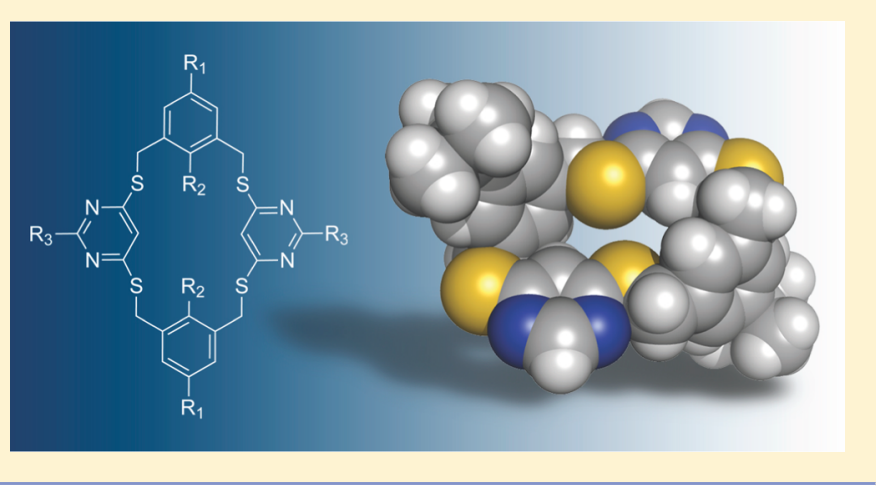

\section{INTRODUCTION}

Heteracalixarenes, ${ }^{1}$ owing to their distinctive features compared to classical calixarenes, have become a subject of growing interest in recent years, among which thiacalixarenes in particular have been investigated the most. Notably, the presence of sulfur atoms instead of methylene bridges gives rise to dipole-dipole interactions between the sulfur atoms and guest species, which endows these macrocycles with many unique and interesting features lacking in the classical calixarene chemistry. Various reports have demonstrated that thiacalixarenes have high potency to act as efficient chelating agents for metal ions/clusters and to form nanoscale coordination cages. $^{1 \mathrm{~b}-\mathrm{d}, 2}$ Oxidation of the bridging sulfur moiety to sulfoxides or sulfones is a modification unique to thiacalixarenes. $^{2 \mathrm{~b}, 3}$ Alteration of the interaction character between complexation of soft to hard metals after oxidation clearly elucidates the role of the bridging moiety on the supramolecular recognition pattern. Recently, the alkylation of the bridging sulfur atoms also was successfully demonstrated. ${ }^{4}$

Homothiacalixarenes are expanded analogues of thiacalixarenes in which $\mathrm{CH}_{2} \mathrm{SCH}_{2}$ bridges replace the sulfur atoms between the aromatic units. ${ }^{5}$ The dimethylenehetero linkages impose an increased cavity size, conformational flexibility, and improved accessibility of the heteroatoms as binding site. Each of these features is beneficial to promote supramolecular interactions via induced-fit toward a certain guest molecule.

$\left[2_{n}\right]$ Thiacalixarenes with $\mathrm{CH}_{2} \mathrm{~S}$ bridging moieties were initially reported to be formed in trace amounts by Vögtle et al. ${ }^{6}$ However, up to the present date, it has been very quiet in this field. A recent revival in the $\left[2_{n}\right]($ oxa/aza $)$ calixarene chemistry was pursued by Wang and co-workers via preparation of several [2.2.1.1]- and [2.2.2.2] tetraheteracalix[2] arene[2]triazines. ${ }^{7}$ To clearly distinguish this class of metacyclophanes with monomethylenehetero linkages and to avoid confusion with the category of homoheteracalixarene with dimethylenehetero bridges (Figure 1), we prefer the term $\left[2_{n}\right]$ heteracalixarenes. The introduction of heteroaromatic units in the calixarenoid framework allows a straightforward nucleophilic aromatic substitution $\left(\mathrm{S}_{\mathrm{N}} \mathrm{Ar}\right)$ reaction as synthetic pathway toward these underexposed heterocalixarenes and the preparation of host systems with unique electronic features and different degrees of conjugation. ${ }^{1}$ Recent studies show that these heterocalixarenes (owing to their multiple binding sites) act as efficient host systems with remarkable binding properties and selective molecular recognition. ${ }^{8}$ Previously, we have optimized an one-pot procedure for homothia- ${ }^{5 \mathrm{~d}}$ and homoselenacalix[4] arenes ${ }^{9}$ and have demonstrated their structural features. Moreover, the selective synthesis of selenacalix[3] triazines, ${ }^{8 n}$ heteracalix[2] arene[2] ${ }^{8}$ yrimidines (with a direct $\mathrm{O} / \mathrm{S}$ bridge), ${ }^{10}$ and a fragment-coupling approach toward larger derivatives ${ }^{11}$ have been established. The presence of pyrimidine moieties has allowed efficient post-macrocyclization modifications which have proven to be beneficial in various supramolecular applications. ${ }^{12}$ This background in calixarene chemistry, together with the availability of dihalopyrimidine and 1,3-phenylenedimethanethiol building blocks, has now prompted us to explore the missing link

Received: June 25, 2012

Published: September 9, 2012 


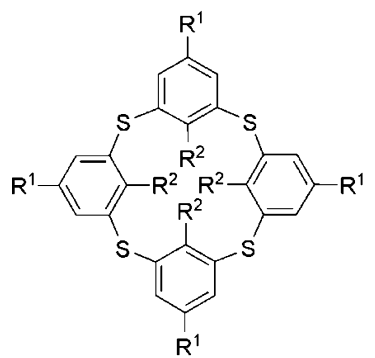

Thiacalix[4]arene

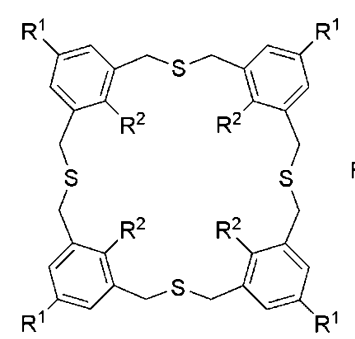

Homothiacalix[4]arene

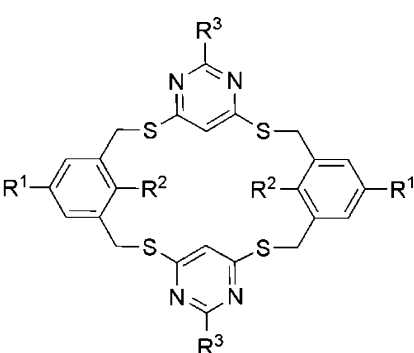

$\left[2_{4}\right]$ thiacalix[2]arene[2]pyrimidine

Figure 1. General representation of the thiacalixarene family with different bridging moieties.

Table 1. $\left[2_{n}\right]$ Thiacalix $[m]$ arene $[m]$ pyrimidine Yield Optimization

\begin{tabular}{|c|c|c|c|c|c|c|c|c|}
\hline entry & base & solvent & conc. $(\mathrm{mM})$ & $T\left({ }^{\circ} \mathrm{C}\right)$ & $t(\mathrm{~h})$ & $3 \mathbf{a}(\%)^{a}$ & $4 \mathbf{a}(\%)^{a}$ & $5 \mathbf{a}(\%)^{a}$ \\
\hline 1 & $\mathrm{~K}_{2} \mathrm{CO}_{3}$ & THF & 6.4 & 50 & 15 & $-b$ & $-b$ & $-b$ \\
\hline 2 & $\mathrm{~K}_{2} \mathrm{CO}_{3}$ & $\mathrm{MeCN}$ & 6.4 & 50 & 15 & 19 & 19 & 41 \\
\hline 3 & $\mathrm{~K}_{2} \mathrm{CO}_{3}$ & DMSO & 6.4 & 50 & 15 & 40 & 22 & 12 \\
\hline 4 & $\mathrm{~K}_{2} \mathrm{CO}_{3}$ & DMAc & 6.4 & 50 & 15 & 33 & 23 & 13 \\
\hline 5 & $\mathrm{~K}_{2} \mathrm{CO}_{3}$ & $\mathrm{EtOH}$ & 6.4 & 50 & 15 & 41 & 20 & 8 \\
\hline 6 & $\mathrm{~K}_{2} \mathrm{CO}_{3}$ & DMF & 6.4 & 50 & 15 & 37 & 21 & 14 \\
\hline 7 & $\mathrm{~K}_{2} \mathrm{CO}_{3}$ & DMF & 6.4 & 50 & 8 & 47 & 19 & 11 \\
\hline 8 & $\mathrm{~K}_{2} \mathrm{CO}_{3}$ & DMF & 6.4 & 50 & 4 & $60\left(57^{c}\right)$ & $13\left(10^{c}\right)$ & $9\left(7^{c}\right)$ \\
\hline $9^{d}$ & $\mathrm{~K}_{2} \mathrm{CO}_{3}$ & DMF & 6.4 & 50 & 4 & 27 & 11 & 7 \\
\hline 10 & $\mathrm{Cs}_{2} \mathrm{CO}_{3}$ & DMF & 6.4 & 50 & 4 & 22 & 27 & 12 \\
\hline 11 & $\mathrm{Na}_{2} \mathrm{CO}_{3}$ & DMF & 6.4 & 50 & 4 & 13 & 3 & -- \\
\hline 12 & $\mathrm{Li}_{2} \mathrm{CO}_{3}$ & DMF & 6.4 & 50 & 4 & $b$ & $b$ & $b$ \\
\hline
\end{tabular}

${ }^{a}$ Based on NMR analysis of the crude reaction mixture. ${ }^{b}$ Inseparable oligomers. ${ }^{c}$ Isolated yield, average of 3 runs. ${ }^{d} 5$ mol $\% 18$-crown- 6 added as catalyst.

between the two classes of homothia- and thiacalixarenes, namely, $\left[2_{n}\right]$ tetrathiacalix $[m]$ arene $[m]$ pyrimidines

\section{RESULTS AND DISCUSSION}

Initially, (5-tert-butyl-2-methoxy-1,3-phenylene)dimethanethiol (1a) and 4,6-dichloro-2-(n-propylsulfanyl)pyrimidine (2a) were combined in equimolar amounts with an excess of $\mathrm{K}_{2} \mathrm{CO}_{3}$ in THF at $50^{\circ} \mathrm{C}$ during $15 \mathrm{~h}$ (Table 1 , entry 1 ), similar to the $\mathrm{S}_{\mathrm{N}} \mathrm{Ar}$ reaction conditions previously optimized for the homothiacalix[4] arenes. ${ }^{5 \mathrm{~d}}$ Unfortunately, mainly acyclic oligomers were observed in the mass spectrum of the reaction mixture and also reactions in NMP and 1,4-dioxane (not shown in Table 1) failed to yield cyclic products. Changing the solvent to $\mathrm{MeCN}$ resulted into a very different outcome.

After separation of the individual $\left[2_{n}\right]$ thiacalix $[m]$ arene $[m]$ pyrimidines $(n=2 m)$, a comparison was made between their ${ }^{1} \mathrm{H}$ NMR spectra. This pointed out a distinct chemical shift for the proton in the $\mathrm{C}_{5}$-position of the pyrimidine moieties, positions 29 and 31, when considering the calix[4]arene numbering scheme (see Supporting Information), that varies with the size of the macroring. A chemical shift of $6.90 \mathrm{ppm}$ is observed for $\left[2_{4}\right]$ thiacalix [4] arene $3 a$, while for $\left[2_{6}\right]$ thiacalix[6] arene $4 \mathbf{a}$ and $\left[2_{8}\right]$ thiacalix[8] arene $5 \mathbf{a}$, a larger upfield shift to $6.48 \mathrm{ppm}$ and $6.61 \mathrm{ppm}$ is found, respectively. This kind of upfield shift for the interior protons of the electrophilic component has been observed before in oxa- and thiacalixarenes and can be attributed to anisotropic effects and conjugation of the S-bridging atoms into the electrophilic aromatic ring. ${ }^{10}$ This peculiarity in chemical shift for the pyrimidine $\mathrm{C}_{5}$-proton was further used as a probe to estimate the percentage of the different macrocycles from the ${ }^{1} \mathrm{H}$ NMR spectra of the crude reaction mixture while optimizing the reaction conditions.

Scheme 1. Synthesis of $\left[2_{n}\right]$ thiacalix $[m]$ arene $[m]$ pyrimidine
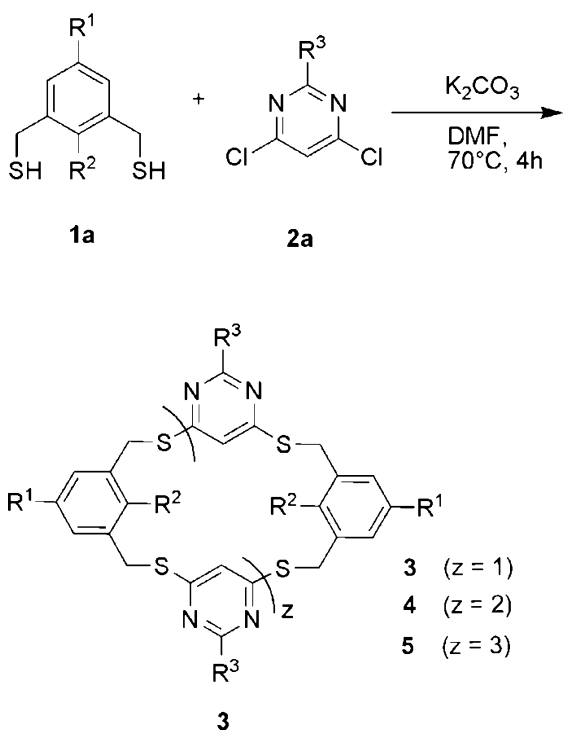

The crude mixture after reaction in $\mathrm{MeCN}$ was estimated to consist of $[24]$ thiacalix[4] arene $3 \mathbf{a}(19 \%)$ and larger macrocyclic species $4 \mathbf{a}(19 \%)$ and 5a (41\%) (Table 1, entry 2). Changing to more polar solvents favored the formation of $3 a$ at the expense of the larger oligomers (entries 3-6, Table 1). Since the smallest cyclic oligomer $3 \mathbf{a}$ is likely to be the more interesting for application in supramolecular chemistry, the 
main focus of optimization was to improve the yield of this macrocycle.

Among the solvents screened (entries 3-6), the usage of more polar solvents like DMSO (entry 3 ), EtOH (entry 5), and DMF (entry 6) improved the yield for $3 a$ to $40 \%, 41 \%$, and $37 \%$, respectively. There, the outcome of the later reactions was very similar, and since in previous work DMF has given excellent results, it was opted to proceed with DMF as the optimal solvent.

Extending the reaction time over $15 \mathrm{~h}$ hardly influenced the result, while a decrease in reaction time to $8 \mathrm{~h}$ resulted in a slight increase to $47 \%$ (entry 7). Further decrease to $4 \mathrm{~h}$ appeared to be even more beneficial for the selectivity toward 3 a with an additional increase of $13 \%$ (entry 8 ); a reaction time of less than $4 \mathrm{~h}$ led to incomplete conversion. The optimal concentration toward the largest amount of $3 a$ was found to be $6.4 \mathrm{mM}$. Changes in concentration of the reagents appeared to play a crucial role in the course of the reaction. Higher concentrations disfavored the formation of macrocycles, while higher dilution did not lead to higher yields. Addition of $5 \mathrm{~mol}$ $\%$ of 18 -crown- 6 as catalyst, which has proven before to be beneficial during oxacalix[2] arene[2] pyrimidine synthesis, ${ }^{10}$ caused a substantial drop in the formation of cyclic oligomers (entry 9). This indicates the importance of a positively charged moiety in the reaction mixture, preorganizing the acyclic oligomers toward macrocyclization. To understand the effect and selectivity of different positively charged species on macrocyclization, different alkali carbonates like $\mathrm{Cs}_{2} \mathrm{CO}_{3}$, $\mathrm{Na}_{2} \mathrm{CO}_{3}$, and $\mathrm{Li}_{2} \mathrm{CO}_{3}$ were screened (entry 10-12), but lower yields were observed in the case of cesium and sodium carbonate whereas lithium carbonate failed to give any cyclic structure. This indicates that the $\mathrm{K}^{+}$cations act as a template to initiate the cyclization. Via chromatographic separation of the most optimal reaction (entry 8 ), the different $\left[2_{n}\right]$ thiacalix $[m]$ arene $[m]$ pyrimidines could be isolated giving pure $\left[2_{4}\right]$ thiacalix $[4]$ arene 3a $(57 \%),\left[2_{6}\right]$ thiacalix$[6]$ arene $4 a(10 \%)$, and $\left[2_{8}\right]$ thiacalix $[8]$ arene $\mathbf{5 a}(7 \%)$ (average of 3 runs).

As previous studies on homoselenacalix [4] arenes ${ }^{9}$ and homothiacalix[4] $\operatorname{arenes}^{10}$ revealed the crucial role of inner rim methoxy group on the macrocyclization, it was thought to study the effect of intra- and extra-annular aryl substituents on the macrocyclization outcome. A major advantage of the pyrimidine moiety as electrophilic building block is the ease in which a diverse substitution pattern can be obtained. ${ }^{13} \mathrm{~A}$ number of 4,6-dichloropyrimidines were reacted with various phenylenedimethanethiol units under the reaction conditions (DMF, $\mathrm{K}_{2} \mathrm{CO}_{3}, 50{ }^{\circ} \mathrm{C}, 4 \mathrm{~h}$ ) previously optimized for $\left[2_{4}\right]$ thiacalix $[4]$ arene $3 \mathbf{a}$ (Table 2$)$.

Hence, reaction of (5-tert-butyl-2-methoxy1,3-phenylene)dimethanethiol (1a) with 4,6-dichloropyrimidine (2b), lacking the $n$-propylsulfanyl group, resulted in only $15 \%$ of tetramer $3 \mathbf{b}$ and $12 \%$ of hexamer $\mathbf{4 b}$ after chromatographic purification (entry 2). This may be due to the loss of product upon purification, which can be attributed to the lower solubility of the product. In fact, we failed to get a sample of $\mathbf{4 b}$ that was completely free of traces of higher oligomers. Similar losses of valuable compound during purification have recently been reported for diazadioxacalix[4] arenes. ${ }^{14}$ Using 4,6-dichloro-2methylsulfanylpyrimidine (2c) or 4,6-dichloro-2-benzylsulfanylpyrimidine (2d) even failed to produce any cyclic compound (entry 3,4$)$.

Combining (5-tert-butyl-1,3-phenylene)dimethanethiol (1b), lacking the methoxy group, and pyrimidine building blocks $\mathbf{2 a -}$
Table 2. Scope of Synthesized $\left[2_{4}\right]$ Thiacalix $[2]$ arene $[2]$ pyrimidines $3 \mathrm{a}-\mathrm{f}$

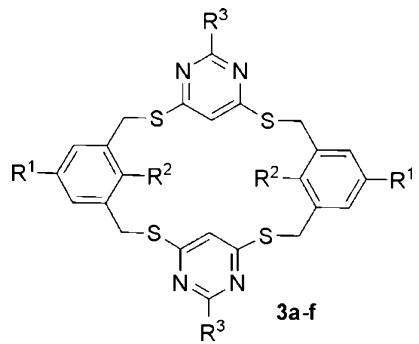

\begin{tabular}{clll} 
entry & \multicolumn{1}{c}{ nucleophile } & \multicolumn{1}{c}{ pyrimidine } & $\mathbf{3}(\%)^{\mathbf{a}}$ \\
$\mathbf{1}$ & $\mathbf{1} \mathbf{a}\left(\mathrm{R}^{1}=t-\mathrm{Bu}, \mathrm{R}^{2}=\mathrm{OMe}\right)$ & $\mathbf{2 a}\left(\mathrm{R}^{3}=\mathrm{SC}_{3} \mathrm{H}_{7}\right)$ & $\mathbf{3 a}(57)$ \\
2 & $\mathbf{1 a}$ & $\mathbf{2 b}\left(\mathrm{R}^{3}=\mathrm{H}\right)$ & $\mathbf{3 b}(15)$ \\
3 & $\mathbf{1 a}$ & $\mathbf{2 c}\left(\mathrm{R}^{3}=\mathrm{SMe}\right)$ & $\mathbf{b}$ \\
4 & $\mathbf{1 a}$ & $\mathbf{2 d}\left(\mathrm{R}^{3}=\mathrm{SBz}\right)$ & $\mathbf{b}$ \\
5 & $\mathbf{1 b}\left(\mathrm{R}^{1}=t-\mathrm{Bu}, \mathrm{R}^{2}=\mathrm{H}\right)$ & $\mathbf{2 a}$ & $3 \mathbf{c}(25)$ \\
6 & $\mathbf{1 b}$ & $\mathbf{2 b}$ & $\mathbf{3 d}(21)$ \\
7 & $\mathbf{1 b}$ & $\mathbf{2 c}$ & $\mathbf{3 e}(26)$ \\
8 & $\mathbf{1 b}$ & $\mathbf{2 d}$ & $\mathbf{3} \mathbf{f}(15)$ \\
9 & $\mathbf{1 c}\left(\mathrm{R}^{1}, \mathrm{R}^{2}=\mathrm{H}\right)$ & $\mathbf{2 a}$ & $b$ \\
10 & $\mathbf{1 d}\left(\mathrm{R}^{1}=\mathrm{H}, \mathrm{R}^{2}=\mathrm{OMe}\right)$ & $\mathbf{2 a}$ & $c$
\end{tabular}

${ }^{a}$ Isolated yields. ${ }^{b}$ Only acyclic oligomers were observed. ${ }^{c}$ Only a trace amount of $\left[2_{4}\right]$ thiacalix[2] arene[2]pyrimidine was observed.

d gave considerably diminished yields for the $\left[2_{4}\right]$ thiacalix $[4]$ arene 3c-3f (15-26\%; entries 5-8). Especially, the collation between cases $1 \mathbf{a}$ with $\mathbf{2 a}(57 \%)$ and $\mathbf{1 b}$ with $\mathbf{2 a}(25 \%)$ suggests that the methoxy group plays a crucial role during the macrocyclization, possibly due to a templating effect. For the reaction of (1,3-phenylene)dimethanethiol (1c), a nucleophilic building block lacking both methoxy and tert-butyl group, with 2a, no cyclic oligomers were observed (Table 2, entry 9). Upon combining (2-methoxy-1,3-phenylene)dimethanethiol (1d), lacking just the tert-butyl moiety, with $2 \mathrm{a}$, a trace amount of product was observed, suggesting that the methoxy group appears to promote the formation of cyclic oligomers. However, due to the low solubility no substantial amount of calixarene could be formed (Table 2, entry 10).

A specific feature attributed to thiacalixarenes is the oxidation of the bridging sulfur atom to sulfoxide and sulfonyl units. ${ }^{1 \mathrm{~b}-\mathrm{d}, 3}$ The sulfonylcalixarenes are known to act as multinucleating or cluster-forming ligands due to their oxygen donors, ${ }^{15}$ which have attracted considerable attention in inner transition metal binding studies due to the promising properties ${ }^{16}$ of their complexes. The presence of the $\mathrm{CH}_{2} \mathrm{~S}$ linkages and the unique cavity size allowed us to oxidize the $\left[2_{4}\right]$ thiacalix $[4]$ arene $3 \mathbf{d}$ to the $\left[2_{4}\right]$ sulfonylcalix[2] arene-[2]pyrimidine $6(71 \%)$ using $m$ $\mathrm{CPBA} / \mathrm{MgSO}_{4}$ in dry dichloromethane at ambient temperature during $15 \mathrm{~h}$.

Solid State Structural Elucidation. Single crystals of compounds $\mathbf{3 d}$ and $\mathbf{3 f}$ suitable for X-ray diffraction analysis were obtained by slow evaporation of a solution of petroleum ether/ethyl acetate and dichloromethane/methanol, respectively. Earlier, it was reported that thiacalix[2] arene[2]pyrimidines in solid state adopt a 1,3-alternate conformation. ${ }^{12 \mathrm{c}}$ The introduction of methylene units into the bridging linkages adversely causes both $\left[22_{4}\right]$ thiacalix [4] arenes $3 \mathbf{d}$ and $3 \mathbf{f}$ to adopt a 1,2-alternate conformation (see Figure 2 for $3 \mathbf{d}$ and Supporting Information for $\mathbf{3 f}$ ). In both molecular structures, the opposing aryl rings as well as the pyrimidine moieties are aligned in parallel planes. In $\mathbf{3 d}$, the pyrimidine units are 
Scheme 2. Synthesis of

$\left[2_{4}\right]$ Sulfonylcalix $[2]$ arene $[2]$ pyrimidine

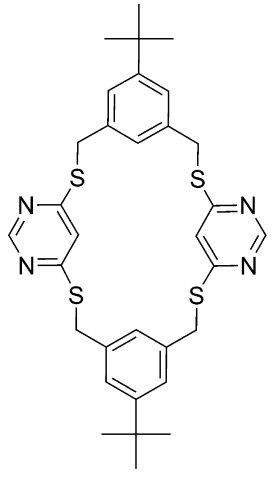

3d
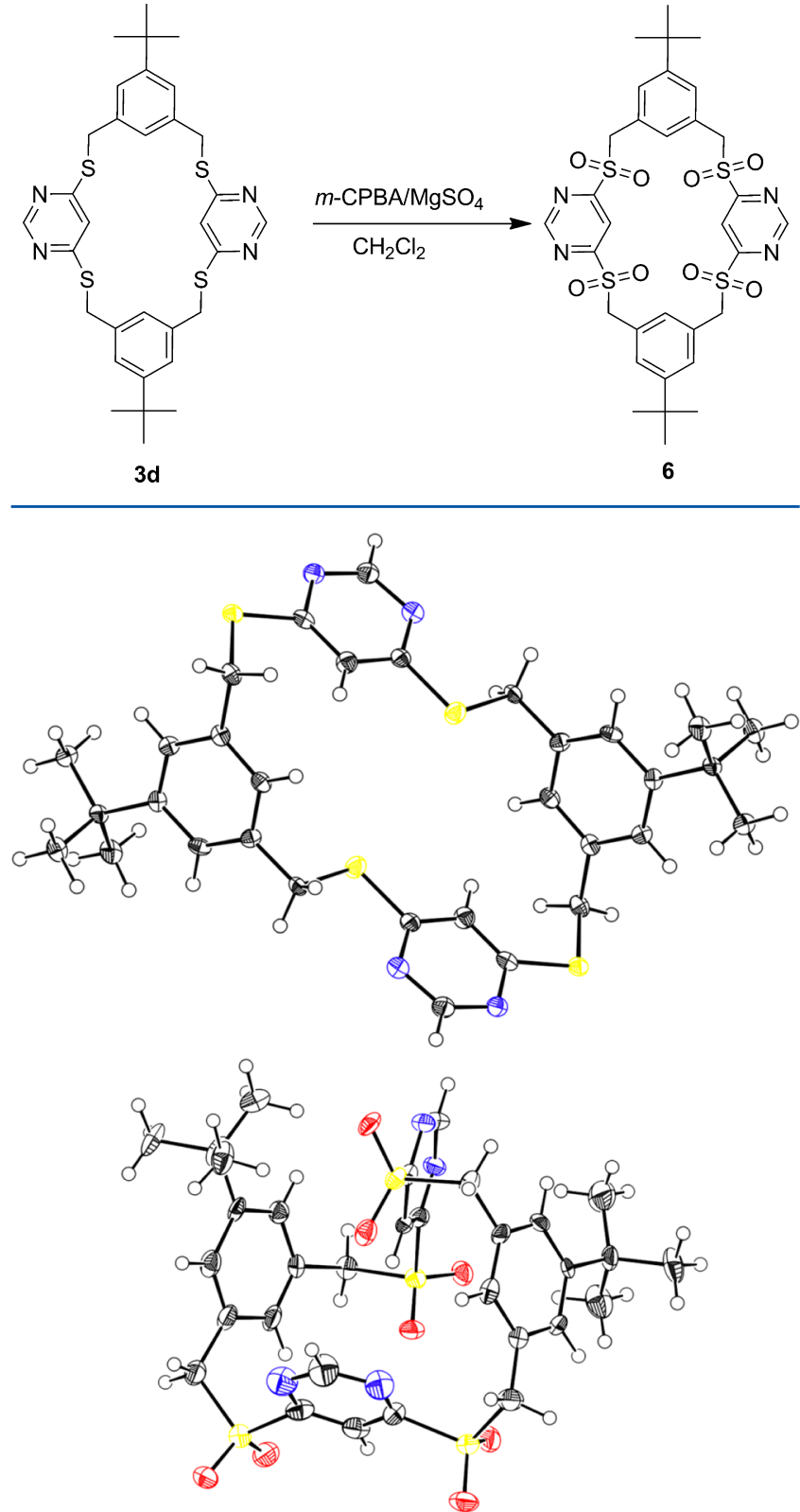

Figure 2. ORTEP representation of $\left[22_{4}\right]$ calix[ $[4]$ arenes $3 \mathbf{d}$ (top) and 6 (bottom, only half of the asymmetric unit is shown) showing thermal ellipsoids at $50 \%$ probability.

pointing outward, while for $\mathbf{3 f}$, they are pointing inward towards the cavity, but in both cases, all four bridging heteroatoms are located on the same plane. More interestingly, for $\mathbf{3 d}$ and $\mathbf{3 f}$ the aryl and pyrimidine ring centroids form a quadrangle with side lengths of $5.30 \times 6.66 \AA^{2}$ and $5.61 \times 5.71$ $\AA^{2}$, respectively (see Supporting Information). These dimensions are notably smaller compared to a homothiacalix [4] arene $\left(6.99 \times 6.99 \AA^{2}\right.$ on average $)$ but larger in comparison to these of a thiacalix[2] arene[2] pyrimidine with single atom linkages $\left(5.02 \times 4.99 \AA^{2}\right) .{ }^{5 \mathrm{~d}, 12 \mathrm{c}}$ This underexplored cavity size can be applied as a new tool toward the selective inclusion of guest molecules. The oxidized analogue 6 adopts in solid state a strongly distorted 1,2-alternate conformation with the pyrimidine rings turning perpendicular to each other while the aryl rings are aligned almost parallel to one another. To the best of our knowledge, these dimensions are unknown among sulfonylcalixarenes, ${ }^{1 \mathrm{~b}-\mathrm{d}, 3}$ opening new possibilities for selective guest inclusion.

\section{CONCLUSIONS}

$\left[2_{4}\right]$ Tetrathiacalix[2] arene[2]pyrimidines, a new class of two atom bridged metacyclophanes, were synthesized via an onepot $S_{N} A r$ reaction. Single-crystal analysis confirmed an, until now, unexplored size among thia- and homothiacalixarenes. Oxidation of the $\mathrm{CH}_{2} \mathrm{~S}$ bridge to a $\mathrm{CH}_{2} \mathrm{SO}_{2}$ unit gave access to a new sulfonylcalixarene with unique dimensions which might introduce unknown metal inclusion aspects to the field of supramolecular chemistry. Both soft and hard metal binding studies are the subject of ongoing research.

\section{EXPERIMENTAL SECTION}

General Experimental Methods. NMR spectra were acquired on commercial instruments, and chemical shifts $(\delta)$ are reported in parts per million (ppm) referenced to tetramethylsilane $\left({ }^{1} \mathrm{H}\right)$ or the internal (NMR) solvent signals $\left({ }^{13} \mathrm{C}\right) \cdot{ }^{17}$ NMR peak assignments were performed based on DEPT and standard 2D NMR methods (HSQC and HMBC). Exact mass measurements were acquired in the EI (at a resolution of 10000 ) or ESI (at a resolution of 60000) mode. Melting points were determined by using a Reichert Thermovar apparatus and were not corrected. For column chromatography, 70230 mesh silica 60 was used as the stationary phase. Chemicals received from commercial sources were used without further purification. $\mathrm{K}_{2} \mathrm{CO}_{3}$ (anhydrous, granulated) was finely ground (with mortar and pestle) and dried overnight in an oven at $200{ }^{\circ} \mathrm{C}$ prior to use.

(5-tert-Butyl-2-methoxy-1,3-phenylene)dimethanethiol (1a). This compound has been prepared according to the procedure reported by Tashiro et al. ${ }^{18}$ Material identity was confirmed by MS and ${ }^{1} \mathrm{H}$ and ${ }^{13} \mathrm{C}$ NMR

(5-tert-Butyl-1,3-phenylene)dimethanethiol (1b). This compound has been prepared according to the procedure reported by Sander et al. ${ }^{19}$ Material identity was confirmed by MS and ${ }^{1} \mathrm{H}$ and ${ }^{13} \mathrm{C}$ NMR.

(2-Methoxy-1,3-phenylene)dimethanethiol (1c). This compound has been prepared according to the procedure reported by Krajulj et al. ${ }^{20}$ Material identity was confirmed by $\mathrm{MS}$ and ${ }^{1} \mathrm{H}$ and ${ }^{13} \mathrm{C}$ NMR.

(1,3-Phenylene)dimethanethiol (1d). This compound has been prepared according to the procedure reported before Ashram et al. ${ }^{21}$ Material identity was confirmed by MS and ${ }^{1} \mathrm{H}$ and ${ }^{13} \mathrm{C}$ NMR.

4,6-Dichloro-2-(propylsulfanyl)pyrimidine (2a). Thiobarbituric acid $(5.0 \mathrm{~g}, 34 \mathrm{mmol})$ and triethylamine $(4.8 \mathrm{~mL}, 34 \mathrm{mmol})$ were dissolved in methanol $(20 \mathrm{~mL})$ and allowed to stir for $5 \mathrm{~min}$. 1Bromopropane $(3.15 \mathrm{~mL}, 34 \mathrm{mmol})$ was added dropwise and the mixture was refluxed for $18 \mathrm{~h}$. The reaction mixture was cooled to room temperature and poured into ice-water. The $\mathrm{pH}$ was adjusted to 1 with $1 \mathrm{M} \mathrm{HCl}$. A pale yellow precipitate was formed, filtered, washed several times with $1 \mathrm{M} \mathrm{HCl}$, and dried under vacuum at $40{ }^{\circ} \mathrm{C}$ (yield $\left.61 \%, \mathrm{mp}>350{ }^{\circ} \mathrm{C}\right)$. The obtained compound was dissolved in $\mathrm{POCl}_{3}$ $(60 \mathrm{~mL})$ and refluxed for $12 \mathrm{~h}$. The reaction mixture was cooled to $\mathrm{rt}$, and the excess of $\mathrm{POCl}_{3}$ was removed under reduced vacuum. The residue was poured into ice-water, extracted with $\mathrm{CH}_{2} \mathrm{Cl}_{2}$, dried over $\mathrm{MgSO}_{4}$, filtered, and concentrated under vacuum. After purification by column chromatography (silica, eluent $\mathrm{CH}_{2} \mathrm{Cl}_{2}$-hexane, 3-7), the desired pyrimidine $\mathbf{2 b}$ was obtained as a colorless liquid $(1.3 \mathrm{~g}, 17 \%)$; MS (EI+) $m / z 223[\mathrm{M}+\mathrm{H}]$; HRMS (EI) calcd for $\mathrm{C}_{7} \mathrm{H}_{8} \mathrm{Cl}_{2} \mathrm{~N}_{2} \mathrm{~S}$ : 221.9785; found: $m / z 221.9783$; ${ }^{1} \mathrm{H}$ NMR $\left(300 \mathrm{MHz}, \mathrm{CDCl}_{3}\right) \delta 6.26$ (s, 1H; 5-pyrim), $3.19\left(\mathrm{t},{ }^{3} \mathrm{~J}=7.2 \mathrm{~Hz}, 2 \mathrm{H} ; \mathrm{CH}_{2}\right), 1.81-1.72(\mathrm{~m}, 2 \mathrm{H}$; $\left.\mathrm{CH}_{2}\right), 1.04\left(\mathrm{t},{ }^{3} \mathrm{~J}=7.1 \mathrm{~Hz}, 3 \mathrm{H} ; \mathrm{CH}_{3}\right) ;{ }^{13} \mathrm{C}$ NMR $\left(100 \mathrm{MHz}, \mathrm{CDCl}_{3}\right) \delta$ 174.4 (C; 2-pyrim), 161.3 (C; 4,6-pyrim), 115.7 ( $\mathrm{CH}$; 5-pyrim), 33.4 $\left(\mathrm{CH}_{2}\right), 22.2\left(\mathrm{CH}_{2}\right), 13.4\left(\mathrm{CH}_{3}\right)$. 
4,6-Dichloro-2-(methylsulfanyl)pyrimidine (2c). This compound has been prepared before by Nugent et al. ${ }^{22}$ Material identity was confirmed by MS and ${ }^{1} \mathrm{H}$ and ${ }^{13} \mathrm{C}$ NMR.

2-(Benzylsulfanyl)-4,6-dichloropyrimidine (2d). This compound has been prepared before by Nugent et al. ${ }^{22}$ Material identity was confirmed by $\mathrm{MS}$ and ${ }^{1} \mathrm{H}$ and ${ }^{13} \mathrm{C}$ NMR.

4,6-Dichloro-2-(methylsulfanyl)pyrimidine-5-carbaldehyde (2e). This compound has been prepared before by Gupton et al. ${ }^{23}$ Material identity was confirmed by MS and ${ }^{1} \mathrm{H}$ and ${ }^{13} \mathrm{C}$ NMR.

5,7,19,21-Tetraaza-13,27-di-tert-butyl-30,32-dimethoxy6,20-dipropylsulfanyl-2,10,16,24-tetrahomo-3,9,17,23tetrathiacalix[4]arene (3a). General procedure 1: (5-tert-Butyl-2methoxy-1,3-phenylene)dimethanethiol (1a) $(100 \mathrm{mg}, 0.39 \mathrm{mmol}, 1$ equiv), 4,6-dichloro-2-(propylsulfanyl)pyrimidine (2a) $(87 \mathrm{mg}, 0.39$ mmol, 1 equiv) and $\mathrm{K}_{2} \mathrm{CO}_{3}$ (135 mg, $0.97 \mathrm{mmol}, 2.5$ equiv) were combined in DMF $(70 \mathrm{~mL})$ and the solution was degassed by a strong argon flow during $15 \mathrm{~min}$. The mixture was stirred at $50{ }^{\circ} \mathrm{C}$ under an argon atmosphere during $4 \mathrm{~h}$ and subsequently evaporated to dryness. The crude residue was redissolved in a mixture of $\mathrm{CH}_{2} \mathrm{Cl}_{2}$ and water. The organic fraction was separated, washed with water, dried with $\mathrm{MgSO}_{4}$, filtered, and concentrated under vacuum. After purification by column chromatography (silica, MPLC, eluent $\mathrm{CH}_{2} \mathrm{Cl}_{2}$-hexane, 8-2), the desired $[24]$ thiacalix[4]arene was obtained as an off-white solid (105 mg, 57\%); mp >300 ${ }^{\circ} \mathrm{C}$; MS (ESI+) $\mathrm{m} / z$ $814.4[\mathrm{MH}+]$; HRMS (EI) calcd for $\mathrm{C}_{40} \mathrm{H}_{53} \mathrm{~N}_{4} \mathrm{O}_{2} \mathrm{~S}_{6}$ : $813.2493[\mathrm{M}+\mathrm{H}]$; found: $\mathrm{m} / z$ 813.2460; ${ }^{1} \mathrm{H}$ NMR (300 MHz, $\left.\mathrm{CDCl}_{3}\right) \delta 7.37$ (s, 4H; Ph), 6.90 (s, $2 \mathrm{H}$; 5-pyrim), 4.18 (s, $\left.8 \mathrm{H} ; \mathrm{CH}_{2}\right), 3.81\left(\mathrm{~s}, 6 \mathrm{H} ; \mathrm{CH}_{3}-\mathrm{O}\right), 3.08\left(\mathrm{t},{ }^{3} \mathrm{~J}=\right.$ $7.2 \mathrm{~Hz}, 4 \mathrm{H} ; \mathrm{CH}_{2}$-propyl), $1.77-1.70$ (m, 4H; $\mathrm{CH}_{2}$-propyl), 1.26 (s, $18 \mathrm{H}, t-\mathrm{Bu}), 1.02\left(\mathrm{t},{ }^{3} \mathrm{~J}=7.2 \mathrm{~Hz}, 6 \mathrm{H} ; \mathrm{CH}_{3}\right) ;{ }^{13} \mathrm{C}$ NMR $(100 \mathrm{MHz}$, $\left.\mathrm{CDCl}_{3}\right) \delta 170.2$ (C; 2-pyrim), 169.3 (C; 4,6-pyrim), 153.9 (C; 5-Ph), $148.1(\mathrm{C} ; 1,3-\mathrm{Ph}), 129.5(\mathrm{C} ; 2-\mathrm{Ph}) .127 .7(\mathrm{CH} ; 4,6-\mathrm{Ph}), 107.8(\mathrm{CH}$; 5-pyrim), $62.94\left(\mathrm{CH}_{3}-\mathrm{O}\right), 34.6(\mathrm{C} ; \mathrm{t}-\mathrm{Bu}), 32.9\left(\mathrm{CH}_{2}\right), 31.5\left(\mathrm{CH}_{3}\right.$; $t$ $\mathrm{Bu}), 28.3\left(\mathrm{CH}_{2}\right), 22.8\left(\mathrm{CH}_{2}\right), 13.6\left(\mathrm{CH}_{3}\right)$. During the synthesis of thiacalix[4]arene $3 \mathrm{a}$, the thiacalix[6]arene $\mathbf{4 a}$ and thiacalix $[8]$ arene $5 \mathbf{a}$ analogue were formed as well.

5,7,19,21,33,35-Hexaaza-13,27,41-tri-tert-butyl-43,45,47-trimethoxy-6,20,34-tripropylsulfanyl-2,10,16,24,30,38-hexahomo-3,9,17,23,31,37-hexathiacalix[6]arene (4a). Yield (8 mg, 10\%); mp: $190-191{ }^{\circ} \mathrm{C}$; MS (ESI+) $m / z 1243.2[\mathrm{M}+\mathrm{Na}]$; HRMS (ESI+) calcd for $\mathrm{C}_{60} \mathrm{H}_{79} \mathrm{~N}_{6} \mathrm{O}_{3} \mathrm{~S}_{9} 1219.3695\left[\mathrm{M}+\mathrm{H}^{+}\right]$; found: $\mathrm{m} / z$ 1219.3690; ${ }^{1} \mathrm{H}$ NMR $\left(300 \mathrm{MHz}, \mathrm{CDCl}_{3}\right) \delta 7.33(\mathrm{~s}, 6 \mathrm{H} ; \mathrm{Ph}), 6.48(\mathrm{~s}$, $3 \mathrm{H}$; 5-pyrim), 4.33 (s, $\left.12 \mathrm{H} ; \mathrm{CH}_{2}\right), 3.79\left(\mathrm{~s}, 9 \mathrm{H} ; \mathrm{CH}_{3}-\mathrm{O}\right), 3.15\left(\mathrm{t},{ }^{3} \mathrm{~J}=\right.$ $\left.7.1 \mathrm{~Hz}, 6 \mathrm{H} ; \mathrm{CH}_{2}\right), 1.84-1.71\left(\mathrm{~m}, 6 \mathrm{H} ; \mathrm{CH}_{2}\right), 1.23(\mathrm{~s}, 27 \mathrm{H} ; t-\mathrm{Bu}), 1.02$ $\left(\mathrm{t},{ }^{3} \mathrm{~J}=7.1 \mathrm{~Hz}, 9 \mathrm{H}, \mathrm{CH}_{3}\right) ;{ }^{13} \mathrm{C}$ NMR $\left(150 \mathrm{MHz}, \mathrm{CDCl}_{3}\right) \delta 170.1(\mathrm{C}$; 2-pyrim), 169.3 (C; 4,6-pyrim), 153.9, (C; 5-Ph), 148.0 (C; 1,3-Ph), $127.7(\mathrm{CH} ; 2,4,6-\mathrm{Ph}), 107.8(\mathrm{CH} ; 5$-pyrim $), 62.9\left(\mathrm{CH}_{3}-\mathrm{O}\right), 34.6(\mathrm{C}$, $t$-Bu $), 32.8\left(\mathrm{CH}_{2}\right), 31.5\left(\mathrm{CH}_{3} ; \mathrm{t}-\mathrm{Bu}\right), 28.3\left(\mathrm{CH}_{2}\right), 22.8\left(\mathrm{CH}_{2}\right), 13.6$ $\left(\mathrm{CH}_{3}\right)$.

$5,7,19,21,33,35,47,49-O c t a a z a-13,27,41,55$-tetra-tert-butyl$43,45,47,49$-quadramethoxy-6,20,34,48-tetrapropylsulfanyl$2,10,16,24,30,38,44,52$-octahomo-3,9,17,23,31,37, 45, 51 octathiacalix[8]arene (5a). Yield (4 mg, 7\%), mp: $209-210{ }^{\circ} \mathrm{C}$; MS $(\mathrm{ESI}+) \mathrm{m} / z \quad 1648.3[\mathrm{MH}+\mathrm{Na}]$; HRMS (ESI+) calcd for $\mathrm{C}_{80} \mathrm{H}_{105} \mathrm{~N}_{8} \mathrm{NaO}_{4} \mathrm{~S}_{12}$ 1648.4805 [MH+Na]; found: $\mathrm{m} / z$ 1648.4809; ${ }^{1} \mathrm{H}$ NMR $\left(300 \mathrm{MHz}, \mathrm{CDCl}_{3}\right) \delta 7.32(\mathrm{~s}, 8 \mathrm{H} ; \mathrm{Ph}), 6.61(\mathrm{~s}, 4 \mathrm{H} ; 5-$ pyrim), 4.39 (s, 16H; $\left.\mathrm{CH}_{2}\right), 3.82\left(\mathrm{~s}, 12 \mathrm{H} ; \mathrm{CH}_{3}-\mathrm{O}\right), 3.13\left(\mathrm{t},{ }^{3} \mathrm{~J}=7.1\right.$ $\left.\mathrm{Hz}, 8 \mathrm{H} ; \mathrm{CH}_{2}\right), 1.82-1.70\left(\mathrm{~m}, 8 \mathrm{H} ; \mathrm{CH}_{2}\right), 1.23(\mathrm{~s}, 36 \mathrm{H} ; \mathrm{t}-\mathrm{Bu}), 1.00(\mathrm{t}$, $\left.{ }^{3} \mathrm{~J}=7.1 \mathrm{~Hz}, 12 \mathrm{H} ; \mathrm{CH}_{3}\right) ;{ }^{13} \mathrm{C} \mathrm{NMR}\left(75 \mathrm{MHz}, \mathrm{CDCl}_{3}\right) \delta 170.8 / 170.5$ (C; 2-pyrim), 167.7/167.2 (C; 4,6-pyrim), 154.6/154.5 (C; 5-Ph), 147.6/147.4 (C; 1,3-Ph), 129.8/129.7 (C; 2-Ph), $127.8(\mathrm{CH} ; 4,6-\mathrm{Ph})$, 110.1/109.7 ( $\mathrm{CH} ; 5$-pyrim), $62.4\left(\mathrm{CH}_{3}-\mathrm{O}\right), 34.5(\mathrm{C} ; \mathrm{t}$ - $\mathrm{Bu}), 33.0$ $\left(\mathrm{CH}_{2}\right), 31.4\left(\mathrm{CH}_{3} ; t-\mathrm{Bu}\right), 28.5\left(\mathrm{CH}_{2}\right), 22.9\left(\mathrm{CH}_{2}\right), 13.6\left(\mathrm{CH}_{3}\right)$.

5,7,19,21-Tetraaza-13,27-di-tert-butyl-30,32-dimethoxy2,10,16,24-tetrahomo-3,9,17,23-tetrathiacalix[4]arene (3b). Synthesis according to general procedure 1 ; (5-tert-butyl-1,3phenylene)dimethanedithiol (1a) (100 mg, $0.389 \mathrm{mmol}$ ), 4,6dichloro-2-(propylsulfanyl)pyrimidine (2b) (58.09 mg, $0.389 \mathrm{mmol}$ ); purification by column chromatography (silica, eluent $\mathrm{CH}_{2} \mathrm{Cl}_{2}-$ hexane, 8-2); Yield: $15 \%(20 \mathrm{mg})$; $\mathrm{mp}>300{ }^{\circ} \mathrm{C}$; MS (ESI+) $\mathrm{m} / \mathrm{z}$ $665.0[\mathrm{MH}+]$; HRMS (ESI+) calcd for $\mathrm{C}_{34} \mathrm{H}_{41} \mathrm{~N}_{4} \mathrm{O}_{2} \mathrm{~S}_{4}$ : $665.2112[\mathrm{M}$ $+\mathrm{H}$; ; found: $m / z 665.2078 ;{ }^{1} \mathrm{H} \mathrm{NMR}\left(300 \mathrm{MHz}, \mathrm{CDCl}_{3}\right) \delta 8.56(\mathrm{~s}$,
2H; 2-pyrim), 7.40 (s, 4H; Ph), 7.23 (s, 2H; 5-pyrim), 4.22 (s, 8H; $\left.\mathrm{CH}_{2}\right), 3.83\left(\mathrm{~s}, 6 \mathrm{H} ; \mathrm{CH}_{3}-\mathrm{O}\right), 1.25(\mathrm{~s}, 18 \mathrm{H} ; t$-Bu). The poor solubility of this compound prevented further characterization by ${ }^{13} \mathrm{C}$ NMR. During the synthesis of thiacalix[4] arene $3 b$, the thiacalix[6] arene $4 b$ analogue was formed as well.

5,7,19,21,33,35-Hexaaza-13,27,41-tri-tert-butyl-43,45,47-trimethoxy-2,10,16,24,30,38-hexahomo-3,9,17,23,31,37hexathiacalix[6]arene (4b). Yield (15 mg, 12\%); mp: $115-116{ }^{\circ} \mathrm{C}$; MS (ESI+) $m / z \quad 1020.4[\mathrm{M}+\mathrm{Na}]$; HRMS (ESI+) calcd for $\mathrm{C}_{51} \mathrm{H}_{61} \mathrm{~N}_{6} \mathrm{O}_{3} \mathrm{~S}_{6}$ : $997.3121[\mathrm{M}+\mathrm{H}]$; found: $m / z$ 997.3119; ${ }^{1} \mathrm{H}$ NMR $\left(300 \mathrm{MHz}, \mathrm{CDCl}_{3}\right) \delta 8.67$ (s, 3H; 2-pyrim), 7.37 (s, 6H; Ph), $6.78(\mathrm{~s}$, $3 \mathrm{H} ; 5$-pyrim), $4.32\left(\mathrm{~s}, 12 \mathrm{H} ; \mathrm{CH}_{2}\right), 3.82\left(\mathrm{~s}, 9 \mathrm{H} ; \mathrm{CH}_{3}-\mathrm{O}\right), 1.22(\mathrm{~s}$, $27 \mathrm{H} ; t-\mathrm{Bu}) ;{ }^{13} \mathrm{C}$ NMR (100 MHz, $\left.\mathrm{CDCl}_{3}\right) \delta 168.9$ (C; 4,6-pyrim), 156.7 (CH; 2-pyrim), 154.5 (C; 2-Ph), 147.7 (C; 5-Ph), 129.3 (C; 1,3 $\mathrm{Ph}), 127.9(\mathrm{CH} ; 4,6-\mathrm{Ph}), 114.1\left(\mathrm{CH} ; 5\right.$-pyrim), $62.5\left(\mathrm{CH}_{3}-\mathrm{O}\right), 34.5$ (C; $t$ - $\mathrm{Bu}), 31.4\left(\mathrm{CH}_{3} ; t-\mathrm{Bu}\right), 28.8\left(\mathrm{CH}_{2}\right)$.

5,7,19,21-Tetraaza-13,27-di-tert-butyl-6,20-dipropylsulfanyl-2,10,16,24-tetrahomo-3,9,17,23-tetrathiacalix[4]arene (3c). Synthesis according to general procedure 1; (5-tert-butyl-1,3phenylene)dimethanedithiol (1b) (100 mg, $0.44 \mathrm{mmol})$, 4,6dichloro-2-(propylsulf-any)pyrimidine (2a) $(0.98 \mathrm{mg}, 0.44 \mathrm{mmol}$ ); purification by column chromatography (silica, eluent petroleum ether $-\mathrm{CH}_{2} \mathrm{Cl}_{2}, 6-4$ ); Yield: $25 \%$ (42 mg); mp: $249-250{ }^{\circ} \mathrm{C}$. MS (ESI +) $m / z 753.4[\mathrm{M}+\mathrm{H}]$; HRMS (ESI+) calcd for $\mathrm{C}_{38} \mathrm{H}_{49} \mathrm{~N}_{4} \mathrm{~S}_{6}: 753.2281$ $[\mathrm{M}+\mathrm{H}]$; found: $m / z 753.2261$; ${ }^{1} \mathrm{H}$ NMR (300 MHz, $\left.\mathrm{CDCl}_{3}\right) \delta 7.39$ (s, 2H; 2-Ph), 7.16 (s, 4H; 4,6-Ph), 6.58 (s, 2H; 5-pyrim), 4.32 (s, 8H; $\left.\mathrm{CH}_{2}\right), 2.93\left(\mathrm{t},{ }^{3} \mathrm{~J}=7.2 \mathrm{~Hz}, 4 \mathrm{H} ; \mathrm{CH}_{2}\right), 1.64-1.59\left(\mathrm{~m}, 4 \mathrm{H} ; \mathrm{CH}_{2}\right), 1.30$ $(\mathrm{s}, 18 \mathrm{H} ; \mathrm{t}-\mathrm{Bu}), 0.88\left(\mathrm{t},{ }^{3} \mathrm{~J}=7.3 \mathrm{~Hz}, 6 \mathrm{H} ; \mathrm{CH}_{3}\right) ;{ }^{13} \mathrm{C} \mathrm{NMR}(75 \mathrm{MHz}$, $\left.\mathrm{CDCl}_{3}\right) \delta 170.8$ (C; 2-pyrim), 167.1 (C; 4,6-pyrim), 151.4 (C; 5-Ph), $138.5(\mathrm{C} ; 1,3-\mathrm{Ph}), 126.0(\mathrm{CH} ; 2-\mathrm{Ph}), 124.5(\mathrm{CH} ; 4,6-\mathrm{Ph}), 110.2(\mathrm{CH}$; 5-pyrim), $34.7(\mathrm{C} ; t-\mathrm{Bu}), 33.2\left(\mathrm{CH}_{2}\right), 33.0\left(\mathrm{CH}_{2}\right), 31.4\left(\mathrm{CH}_{3} ; t-\mathrm{Bu}\right)$, $22.8\left(\mathrm{CH}_{2}\right), 13.5\left(\mathrm{CH}_{3}\right)$. During the synthesis of thiacalix[4]arene $3 \mathrm{c}$, the thiacalix[6] arene $4 \mathbf{c}$ analogue was formed as well.

5,7,19,21,33,35-Hexaaza-13,27,41-tri-tert-butyl-6,20,34-tripropylsulfanyl-2,10,16,24,30,38-hexahomo-3,9,17,23,31,37hexathiacalix[6]arene (4c). Yield (22 mg, 13\%), mp: $120-121{ }^{\circ} \mathrm{C}_{i}$ MS (ESI+) $m / z 1129.5[\mathrm{M}+\mathrm{H}]$; HRMS (ESI+) calcd for $\mathrm{C}_{57} \mathrm{H}_{73} \mathrm{~N}_{6} \mathrm{~S}_{9}$ : $1129.3378\left[\mathrm{M}+\mathrm{H}^{+}\right]$; found: $m / z$ 1129.3349; ${ }^{1} \mathrm{H}$ NMR $(300 \mathrm{MHz}$, $\left.\mathrm{CDCl}_{3}\right) \delta 7.23(\mathrm{~s}, 9 \mathrm{H} ; \mathrm{Ph}), 6.60$ (s, 3H; 5-pyrim), $4.33\left(\mathrm{~s}, 12 \mathrm{H} ; \mathrm{CH}_{2}\right)$, $3.01\left(\mathrm{t},{ }^{3} \mathrm{~J}=7.2 \mathrm{~Hz}, 6 \mathrm{H} ; \mathrm{CH}_{2}\right), 1.73-1.63\left(\mathrm{~m}, 6 \mathrm{H} ; \mathrm{CH}_{2}\right), 1.28(\mathrm{~s}$, $27 \mathrm{H} ; t-\mathrm{Bu}), 0.90\left(\mathrm{t},{ }^{3} \mathrm{~J}=7.3 \mathrm{~Hz}, 9 \mathrm{H} ; \mathrm{CH}_{3}\right) ;{ }^{13} \mathrm{C} \mathrm{NMR}(75 \mathrm{MHz}$, $\left.\mathrm{CDCl}_{3}\right) \delta 171.0$ (C; 2-pyrim), 167.4 (C; 4,6-pyrim), 151.9 (C; 5-Ph), $137.3(\mathrm{C} ; 1,3-\mathrm{Ph}), 126.7(\mathrm{CH} ; 2-\mathrm{Ph}), 125.1(\mathrm{CH} ; 4,6-\mathrm{Ph}), 110.3(\mathrm{CH}$; 5-pyrim), $34.8(\mathrm{C} ; t$-Bu $), 33.7\left(\mathrm{CH}_{2}\right), 32.9\left(\mathrm{CH}_{2}\right), 31.4\left(\mathrm{CH}_{3} ; t\right.$-Bu $)$, $29.8\left(\mathrm{CH}_{2}\right), 22.9\left(\mathrm{CH}_{2}\right), 13.5\left(\mathrm{CH}_{3}\right)$.

5,7,19,21-Tetraaza-13,27-di-tert-butyl-2,10,16,24-tetrahomo-3,9,17,23-tetrathiacalix[4]arene (3d). Synthesis according to general procedure 1; (5-tert-butyl-1,3-phenylene)dimethanedithiol (1b) (100 mg, $0.44 \mathrm{mmol})$, 4,6-dichloropyrimidine (2b) (0.65 mg, $0.44 \mathrm{mmol}$ ); purification by column chromatography (silica, eluent petroleum ether-ethyl acetate, 7-3); Yield: 26\% (35 mg); mp: 249$250{ }^{\circ} \mathrm{C}$; MS (ESI+) $\mathrm{m} / z$ 605.3 [M+H]; HRMS (ESI+) calcd for $\mathrm{C}_{32} \mathrm{H}_{37} \mathrm{~N}_{4} \mathrm{~S}_{4}: 605.1901[\mathrm{M}+\mathrm{H}]$; found: $m / z$ 605.1901; ${ }^{1} \mathrm{H}$ NMR $(300$ $\left.\mathrm{MHz}, \mathrm{CDCl}_{3}\right) \delta 8.52$ (s, 2H; 2-pyrim), $7.46(\mathrm{~s}, 2 \mathrm{H} ; 2-\mathrm{Ph}), 7.19(\mathrm{~s}, 4 \mathrm{H}$; 4,6-Ph), 6.78 (s, 2H; 5-pyrim), $4.29\left(\mathrm{~s}, 8 \mathrm{H} ; \mathrm{CH}_{2}\right), 1.28(\mathrm{~s}, 18 \mathrm{H} ; \mathrm{t}-\mathrm{Bu})$; ${ }^{13} \mathrm{C}$ NMR $\left(75 \mathrm{MHz}, \mathrm{CDCl}_{3}\right) \delta 167.4(\mathrm{C} ; 4,6$-pyrim), 156.6 (C; 2pyrim), 151.9 (C; 5-Ph), 138.0 (C; 1,3-Ph), $126.8(\mathrm{CH} ; 2-\mathrm{Ph}), 125.0$ $(\mathrm{CH} ; 4,6-\mathrm{Ph}), 115.0\left(\mathrm{CH} ; 5\right.$-pyrim), $34.8(\mathrm{C} ; \mathrm{t}$ - $\mathrm{Bu}), 33.2\left(\mathrm{CH}_{2}\right), 31.4$ $\left(\mathrm{CH}_{3} ; t-\mathrm{Bu}\right)$. During the synthesis of thiacalix[4]arene $3 \mathrm{~d}$, the thiacalix[6] arene $4 \mathrm{~d}$ analogue was formed as well.

$5,7,19,21,33,35$-Hexaaza-13,27,41-tri-tert-butyl$2,10,16,24,30,38$-hexahomo-3,9,17,23,31,37-hexathiacalix [6]arene (4d). Yield (45 mg, 34\%); mp: $107-108{ }^{\circ} \mathrm{C}$; MS (ESI+) $\mathrm{m} / z$ $930.6[\mathrm{M}+\mathrm{Na}]$; HRMS (ESI+) calcd for $\mathrm{C}_{48} \mathrm{H}_{55} \mathrm{~N}_{6} \mathrm{~S}_{6}: 907.2812[\mathrm{M}$ $+\mathrm{H}$ ]; found: $m / z$ 907.2801; ${ }^{1} \mathrm{H} \mathrm{NMR}\left(300 \mathrm{MHz}, \mathrm{CDCl}_{3}\right) \delta 8.65$ (s, $3 \mathrm{H}$; 2-pyrim), 7.25 (s, 9H; Ph), 6.89 (s, 3H; 5-pyrim), 4.33 (s, 12H; $\left.\mathrm{CH}_{2}\right), 1.28(\mathrm{~s}, 27 \mathrm{H} ; \mathrm{t}-\mathrm{Bu}) ;{ }^{13} \mathrm{C} \mathrm{NMR}\left(75 \mathrm{MHz}, \mathrm{CDCl}_{3}\right) \delta 167.8 / 167.7$ (C; 4,6-pyrim), 157.0 (CH; 2-pyrim), $152.0(\mathrm{C}$; 5-Ph), 137.14/137.11 (C; 1,3-Ph), $126.7(\mathrm{CH} ; 2-\mathrm{Ph}), 125.4 / 125.3(\mathrm{CH} ; 4,6-\mathrm{Ph}), 115.1$ (CH; 5-pyrim), $34.7(\mathrm{C} ; t-\mathrm{Bu}), 33.9\left(\mathrm{CH}_{2}\right), 31.3\left(\mathrm{CH}_{3} ; t\right.$-Bu). 
5,7,19,21-Tetraaaza-13,27-di-tert-butyl-6,20-dimethylsulfanyl-2,10,16,24-tetrahomo-3,9,17,23-tetrathiacalix[4]arene (3e). Synthesis according to general procedure 1; (5-tert-butyl-1,3phenylene)dimethanedithiol (1b) (100 mg, $0.44 \mathrm{mmol}), 4,6-$ dichloro-2-(methylsulfanyl)pyrimidine (2c) $(0.86 \mathrm{mg}, 0.44 \mathrm{mmol})$; purification by column chromatography (silica, eluent petroleum ether- $\mathrm{CH}_{2} \mathrm{Cl}_{2}, 7-3$ ); Yield: $26 \%$ (40 mg); mp: 264-265 ${ }^{\circ} \mathrm{C}$; MS (ESI+) $\mathrm{m} / z$ 697.9 $[\mathrm{M}+\mathrm{H}]$; HRMS (ESI+) calcd for $\mathrm{C}_{34} \mathrm{H}_{41} \mathrm{~N}_{4} \mathrm{~S}_{6}$ : $697.1655[\mathrm{M}+\mathrm{H}]$; found: $m / z$ 697.1680; ${ }^{1} \mathrm{H}$ NMR (300 MHz, $\left.\mathrm{CDCl}_{3}\right) \delta 7.41(\mathrm{~s}, 2 \mathrm{H} ; 2-\mathrm{Ph}), 7.15(\mathrm{~s}, 4 \mathrm{H} ; 4,6-\mathrm{Ph}), 6.58(\mathrm{~s}, 2 \mathrm{H} ; 5-$ pyrim), $4.33\left(\mathrm{~s}, 8 \mathrm{H} ; \mathrm{CH}_{2}\right), 2.38\left(\mathrm{~s}, 6 \mathrm{H} ; \mathrm{CH}_{3}\right), 1.30(\mathrm{~s}, 18 \mathrm{H} ; t-\mathrm{Bu}) ;{ }^{13} \mathrm{C}$ NMR (75 MHz, $\mathrm{CDCl}_{3}$ ) $\delta 171.0$ (2-pyrim), 167.1 (C; 4,6-pyrim), $151.4(\mathrm{C} ; 5-\mathrm{Ph}), 138.6(\mathrm{C} ; 1,3-\mathrm{Ph}), 126.0(\mathrm{CH} ; 2-\mathrm{Ph}), 124.5(\mathrm{CH}$; 4,6-Ph), $110.2\left(\mathrm{CH}\right.$; 5-pyrim), $34.7(\mathrm{C}$; $t$ - $\mathrm{Bu}), 33.2\left(\mathrm{CH}_{2}\right), 31.5\left(\mathrm{CH}_{3}\right.$; $t$-Bu $), 14.2\left(\mathrm{CH}_{3}-\mathrm{S}\right)$. During the synthesis of thiacalix [4] arene $3 \mathbf{e}$, the thiacalix[6] arene $4 \mathrm{e}$ analogue was formed as well.

5,7,19,21,33,35-Hexaaza-13,27,41-tri-tert-butyl-6,20,34-trimethylsulfanyl-2,10,16,24,30,38-hexahomo-3,9,17,23,31,37hexathiacalix[6]arene (4e). Yield (10 mg, 7\%); mp: $87-88^{\circ} \mathrm{C}$; MS $(\mathrm{ESI}+) \mathrm{m} / z$ 1047.1 [MH+], 1068.4 [M+Na]; HRMS (ESI+) calcd for $\mathrm{C}_{51} \mathrm{H}_{60} \mathrm{~N}_{6} \mathrm{NaS}_{9}$ : $1067.2264\left[\mathrm{M}+\mathrm{Na}\right.$ ]; found: $m / z$ 1067.2244; ${ }^{1} \mathrm{H}$ NMR $\left(300 \mathrm{MHz}, \mathrm{CD}_{2} \mathrm{Cl}_{2}\right) \delta 7.18(\mathrm{~s}, 3 \mathrm{H} ; 2-\mathrm{Ph}), 7.16(\mathrm{~s}, 6 \mathrm{H} ; 4,6-\mathrm{Ph}), 6.56$ (s, 3H; 5-pyrim), $4.27\left(\mathrm{~s}, 12 \mathrm{H} ; \mathrm{CH}_{2}\right), 2.34\left(\mathrm{~s}, 9 \mathrm{H} ; \mathrm{CH}_{3}\right), 1.20(\mathrm{~s}, 18 \mathrm{H}$; $t$-Bu); ${ }^{13} \mathrm{C}$ NMR (75 MHz, $\left.\mathrm{CDCl}_{3}\right) \delta 167.3$ (C; 2,4,6-pyrim), 151.9 (C; 5-Ph), 137.5 (C; 1,3-Ph), $126.6(\mathrm{CH} ; 2-\mathrm{Ph}), 125.1(\mathrm{CH} ; 4,6-\mathrm{Ph})$, $110.3\left(\mathrm{CH} ; 5\right.$-pyrim), $34.8(\mathrm{C} ; t-\mathrm{Bu}), 33.7\left(\mathrm{CH}_{2}\right), 31.4\left(\mathrm{CH}_{3} ; t-\mathrm{Bu}\right)$, $14.2\left(\mathrm{CH}_{3}-\mathrm{S}\right)$.

5,7,19,21-Tetraaza-13,27-di-tert-butyl-6,20-diphenylsulfanyl-2,10,16,24-tetrahomo-3,9,17,23-tetrathiacalix[4]arene (3f). Synthesis according to general procedure 1; (5-tert-butyl-1,3phenylene)dimethanedithiol (1b) (100 mg, $0.44 \mathrm{mmol}), 2$-(benzylsulfanyl)-4,6-dich-loropyrimidine (2d) (119 mg, $0.44 \mathrm{mmol}$ ); purification by column chromatography (silica, eluent petroleum ether- $\mathrm{CH}_{2} \mathrm{Cl}_{2}, 7-3$ ); Yield: $40 \%$ (70 mg); mp: $210-211{ }^{\circ} \mathrm{C}$; MS (ESI+) $m / z$ 850.8 [M+H]; HRMS (ESI+) calcd for $\mathrm{C}_{46} \mathrm{H}_{49} \mathrm{~N}_{4} \mathrm{~S}_{6}$ : $849.2281[\mathrm{M}+\mathrm{H}]$; found: $m / z$ 849.2248; ${ }^{1} \mathrm{H}$ NMR $(300 \mathrm{MHz}$, $\left.\mathrm{CDCl}_{3}\right) \delta 7.43(\mathrm{~s}, 2 \mathrm{H} ; 2-\mathrm{Ph}), 7.24-7.19(\mathrm{~m}, 10 \mathrm{H}$; benzyl), $7.14(\mathrm{~s}$, $4 \mathrm{H} ; 4,6-\mathrm{Ph}), 6.64$ (s, $2 \mathrm{H} ; 5$-pyrim), $4.27\left(\mathrm{~s}, 8 \mathrm{H} ; \mathrm{CH}_{2}\right), 4.18$ (s, $4 \mathrm{H}$; $\left.\mathrm{CH}_{2}\right), 1.26(\mathrm{~s}, 18 \mathrm{H} ; t-\mathrm{Bu}) ;{ }^{13} \mathrm{C} \mathrm{NMR}\left(100 \mathrm{MHz}, \mathrm{CDCl}_{3}\right) \delta 170.3(\mathrm{C}$; 2-pyrim), 167.3 (C; 4,6-pyrim), 151.5 (C; 5-Ph), 138.5 (C; 1,3-Ph), 137.4 (C; ipso-benz), 128.9 (C; m-benz), 128.5 (C; o-benz), 127.1 (C; p-benz), $126.1(\mathrm{CH} ; 2-\mathrm{Ph}), 124.5(\mathrm{CH} ; 4,6-\mathrm{Ph}), 110.6(\mathrm{CH} ; 5$-pyrim $)$, $35.4\left(\mathrm{CH}_{2}\right.$-benz $), 34.7(\mathrm{C} ; \mathrm{t}$ - $\mathrm{Bu}), 33.4\left(\mathrm{CH}_{2}\right), 31.4\left(\mathrm{CH}_{3} ; t\right.$ - $\left.\mathrm{Bu}\right)$. During the synthesis of thiacalix[4]arene $3 \mathrm{f}$, the thiacalix[6]arene $\mathbf{4 f}$ analogue was formed as well.

$5,7,19,21,33,35$-Hexaaza-13,27,41-tri-tert-buty-6,20,34-triphenylsulfanyl-2,10,16,24,30,38-hexahomo-3,9,17,23,31,37hexathiacalix[6]arene (4f). Yield $(10 \mathrm{mg}, 5 \%)$; mp: $104-105{ }^{\circ} \mathrm{C}$; MS (ESI+) $m / z$ 1312 [M+K]; HRMS (ESI+) $m / z$ calcd for $\mathrm{C}_{69} \mathrm{H}_{73} \mathrm{~N}_{6} \mathrm{~S}_{9}: 1273.3383[\mathrm{M}+\mathrm{H}]$; found: $m / z ; 1273.3380 ;{ }^{1} \mathrm{H}$ NMR $\left(300 \mathrm{MHz}, \mathrm{CDCl}_{3}\right) \delta 7.30(\mathrm{~s}, 3 \mathrm{H}), 7.28(\mathrm{~s}, 3 \mathrm{H}), 7.22(\mathrm{~s}, 12 \mathrm{H}), 7.20-$ $7.14(\mathrm{~m}, 6 \mathrm{H}), 6.57\left(\mathrm{~s}, 3 \mathrm{H} ; 5\right.$-pyrim), $4.31\left(\mathrm{~s}, 6 \mathrm{H} ; \mathrm{CH}_{2}\right), 4.27(\mathrm{~s}, 12 \mathrm{H}$; $\left.\mathrm{CH}_{2}\right), 1.26(\mathrm{~s}, 27 \mathrm{H} ; t-\mathrm{Bu}) ;{ }^{13} \mathrm{C} \mathrm{NMR}\left(100 \mathrm{MHz}, \mathrm{CDCl}_{3}\right) \delta 170.3(\mathrm{C}$; 2-pyrim), 167.6 (C; 4,6-pyrim), 151.9 (C; 5-Ph), 137.4 (C; ipso-benz), 137.2 (C; 1,3-Ph), 128.9 (C; $m$-benz), 128.6 (C; o-benz), 127.2 (C; $p$ benz), 126.7 (CH; 2-Ph), $125.2(\mathrm{CH} ; 4,6-\mathrm{Ph}), 110.5(\mathrm{CH} ; 5$-pyrim), $35.4\left(\mathrm{CH}_{2}\right.$-benz), $34.8(\mathrm{C} ; \mathrm{t}$ - $\mathrm{Bu}), 33.8\left(\mathrm{CH}_{2}\right), 31.4\left(\mathrm{CH}_{3} ; t\right.$ - $\left.\mathrm{Bu}\right)$.

5,7,19,21-Tetraaza-13,27-di-tert-butyl-2,10,16,24-tetrahomo-3,9,17,23-tetrasulfonylcalix[4]arene (6). $\mathrm{m}$-CPBA (356 mg, $2.06 \mathrm{mmol}, 12$ equiv) and $\mathrm{MgSO}_{4}(248 \mathrm{mg}, 2.06 \mathrm{mmol}$ ) were mixed together in $\mathrm{CH}_{2} \mathrm{Cl}_{2}(10 \mathrm{~mL})$ and stirred for $1 \mathrm{~h}$ at RT. Subsequently, thiacalix[4]arene $3 \mathrm{~d}(100 \mathrm{mg}, 0.17 \mathrm{mmol}, 1$ equiv) was added and the mixture was stirred at RT for $12 \mathrm{~h}$ (under Ar). The resulting solution was filtered, diluted with $\mathrm{MeOH}(20 \mathrm{~mL})$, and $\mathrm{CH}_{2} \mathrm{Cl}_{2}$ was carefully evaporated in vacuum, resulting in the formation of a white crystalline solid, which was filtered off and washed with $\mathrm{MeOH}$ to afford calix[4] arene 6 as an off-white solid. Yield: 71\% (90 mg); mp: 304$305{ }^{\circ} \mathrm{C}$; MS (ESI+) $\mathrm{m} / z 755[\mathrm{M}+\mathrm{Na}]$; HRMS (ESI+) calcd for $\mathrm{C}_{32} \mathrm{H}_{37} \mathrm{~N}_{4} \mathrm{O}_{8} \mathrm{~S}_{4}$ : 733.1494; found: $m / z 733.1481$; ${ }^{1} \mathrm{H}$ NMR $(300 \mathrm{MHz}$, $\left.\mathrm{CDCl}_{3}\right) \delta 9.37$ (s, 2H; 2-pyrim), 7.63 (s, 2H; 2-Ph), 7.15 (s, 2H; 5- pyrim), 7.09 ppm (s, 4H; 4,6-Ph), 4.60 (s, $\left.8 \mathrm{H} ; \mathrm{CH}_{2}\right), 1.14$ (s, $18 \mathrm{H} ;$ $\mathrm{Bu}) ;{ }^{13} \mathrm{C} \mathrm{NMR}\left(75 \mathrm{MHz}, \mathrm{CDCl}_{3}\right) \delta 167.2$ (C; 4,6-pyrim), $159.1(\mathrm{CH}$; 2-pyrim), $153.2(\mathrm{C} ; 5-\mathrm{Ph}), 130.4(\mathrm{CH} ; 2-\mathrm{Ph}), 128.8(\mathrm{CH} ; 4,6-\mathrm{Ph})$, $127.3(\mathrm{C} ; 1,3-\mathrm{Ph}), 116.0\left(\mathrm{CH} ; 5\right.$-pyrim), $58.3\left(\mathrm{CH}_{2}\right), 34.7(\mathrm{C} ; t-\mathrm{Bu})$, $31.1\left(\mathrm{CH}_{3} ; \mathrm{t}-\mathrm{Bu}\right)$.

\section{ASSOCIATED CONTENT}

\section{Supporting Information}

Additional X-ray data (CIF), copies of ${ }^{1} \mathrm{H}$ and ${ }^{13} \mathrm{C}$ NMR spectra. This material is available free of charge via the Internet at http://pubs.acs.org.

\section{AUTHOR INFORMATION}

\section{Corresponding Author}

*E-mail: wim.dehaen@chem.kuleuven.be

\section{Present Address}

${ }^{\S}$ World Premier International (WPI) Research Center for Materials Nanoarchitectonics (MANA), National Institute for Materials Science (NIMS), 1-1 Namiki, Tsukuba, Ibaraki 305-0044, Japan.

\section{Notes}

The authors declare no competing financial interest.

\section{ACKNOWLEDGMENTS}

Erasmus Mundus Lot 13, Euro-India is acknowledged for the doctoral fellowship to MPS. We thank the Fonds voor Wetenschappelijk Onderzoek (FWO) and the University of Leuven for financial support. Mass spectrometry was made possible by the support of the Hercules Foundation of the Flemish Government (grant 20100225-7).

\section{REFERENCES}

(1) Heteracalixarene reviews: (a) Konig, B.; Fonseca, M. H. Eur. J. Inorg. Chem. 2000, 2303. (b) Lhotak, P. Eur. J. Org. Chem. 2004, 1675. (c) Morohashi, N.; Narumi, F.; Iki, N.; Hattori, T.; Miyano, S. Chem. Rev. 2006, 106, 5291. (d) Kajiwara, T.; Iki, N.; Yamashita, M. Coord. Chem. Rev. 2007, 251, 1734. (e) Tsue, H.; Ishibashi, K.; Tamura, R. Top. Heterocycl. Chem. 2008, 17, 73. (f) Maes, W.; Dehaen, W. Chem. Soc. Rev. 2008, 37, 2393. (g) Wang, M.-X. Chem. Commun. 2008, 4541;(h) Acc. Chem. Res. 2012, 45, 182.

(2) (a) Iki, N.; Morohashi, N.; Narumi, F.; Miyano, S. Bull. Chem. Soc. Jpn. 1998, 71, 1597. (b) Morohashi, N.; Iki, N.; Sugawara, A.; Miyano, S. Tetrahedron 2001, 57, 5557. (c) Kajiwara, T.; Kon, N.; Yokozawa, S.; Ito, T.; Iki, N.; Miyano, S. J. Am. Chem. Soc. 2002, 124, 11274. (d) Sykora, J.; Hilm, M.; Stibor, I.; Cisarova, I.; Lhotak, P. Tetrahedron 2007, 63, 2244. (e) Iki, N.; Hiro-oka, S.; Tanaka, T.; Kabuto, C.; Hoshino, H. Inorg. Chem. 2012, 51, 1648. (f) Liu, M.; Liao, W.; Hu, C.; Du, S.; Zhang, H. Angew. Chem., Int. Ed. 2012, 51, 1585.

(3) (a) Mislin, G.; Graf, E.; Hosseini, M. W.; De Cian, A.; Fischer, J. Chem. Commun. 1998, 1345. (b) Kajiwara, T.; Wu, H.; Ito, T.; Iki, N.; Miyano, S. Angew. Chem., Int. Ed. 2004, 43, 1832. (c) Kajiwara, T.; Katagiri, K.; Hasegawa, M.; Ishii, A.; Ferbinteanu, M.; Takaishi, S.; Ito, T.; Yamashita, M.; Iki, N. Inorg. Chem. 2006, 45, 4880. (d) Kajiwara, T.; Hasegawa, M.; Ishii, A.; Katagiri, K.; Baatar, M.; Takaishi, S.; Iki, N.; Yamashita, M. Eur. J. Inorg. Chem. 2008, 5565. (e) Dai, F.-R.; Wang, Z. J. Am. Chem. Soc. 2012 DOI: 10.1021/ja300095j.

(4) (a) Kundrat, O.; Eigner, V.; Dvorakova, H.; Lhotak, P. Org. Lett. 2011, 13, 4032. (b) Kundrat, O.; Dvorakova, H.; Bohm, S.; Eigner, V.; Lhotak, P. J. Org. Chem. 2012, 77, 2272.

(5) (a) Mitchell, R. H.; Boekelheide, V. J. Am. Chem. Soc. 1974, 96, 1547. (b) Ashram, M. J. Inclusion Phenom. Macrocyclic Chem. 2006, 54, 253. (c) Tran, H.-A.; Georghiou, P. E. New J. Chem. 2007, 31, 921. (d) Thomas, J.; Van Hecke, K.; Robeyns, K.; Van Rossom, W.; Sonawane, M. P.; Van Meervelt, L.; Smet, M.; Maes, W.; Dehaen, W. Chem.-Eur. J. 2011, 17, 10339. 
(6) (a) Vögtle, F. Tetrahedron Lett. 1968, 32, 3623. (b) Vögtle, F.; Neumann, P. Tetrahedron Lett. 1970, 2, 115.

(7) Chen, Y.; Wang, D.-X.; Huang, Z.-T.; Wang, M.-X. J. Org. Chem. 2010, 75, 3786.

(8) (a) Miyazaki, Y.; Kanbara, T.; Yamamoto, T. Tetrahedron Lett. 2002, 43, 7945. (b) Suzuki, Y.; Yanagi, T.; Kanbara, T.; Yamamoto, T. Synlett 2005, 2, 263. (c) Sessler, J. L.; Gross, D. E.; Cho, W.-S.; Lynch, V. M.; Schmidtchen, F. P.; Bates, G. W.; Light, M. E.; Gale, P. A. J. Am. Chem. Soc. 2006, 128, 12281. (d) Katz, J. L.; Geller, B. J.; Foster, P. D. Chem. Commun. 2007, 1026. (e) Ma, M.-L.; Li, X.-Y.; Wen, K. J. Am. Chem. Soc. 2009, 131, 8338. (f) Uchida, N.; Taketoshi, A.; Kuwabara, J.; Yamamoto, T.; Inoue, Y.; Watanabe, Y.; Kanbara, T. Org. Lett. 2010, 12, 5242. (g) Ma, M.-L.; Li, X.-Y.; Zhao, X.-L.; Guo, F.; Jiang, B.; Wen, K. Cryst. Eng. Comm. 2011, 13, 1752. (h) Chen, Y.; Wang, D.-X.; Huang, Z.-T.; Wang, M.-X. Chem. Commun. 2011, 47, 8112. (i) Wang, M.-X. Acc. Chem. Res. 2012, 45, 182. (j) Guan, A.-J.; Zhang, E.-X.; Xiang, J.-F.; Li, Q.; Yang, Q.-F.; Li, L.; Tang, Y.-L.; Wang, M.-X. J. Phys. Chem. $B$ 2011, 115, 12584. (k) Li., S.; Fa, S.-X.; Wang, Q.-Q.; Wang, D.-X.; Wang, M.-X. J. Org. Chem. 2012, 77, 1860. (1) Wu, J.-C.; Zhao, L.; Wang, D.-X.; Wang, M.-X. Inorg. Chem. 2012, 51, 3860. (m) Vicente, A. I.; Caio, J, M.; Sardinha, J.; Moiteiro, C.; Delgado, R.; Felix, V. Tetrahedron 2012, 68, 670. (n) Thomas, J.; Van Rossom, W.; Van Hecke, K.; Van Meervelt, L.; Smet, M.; Maes, W.; Dehaen, W. Chem. Commun. 2012, 48, 43.

(9) (a) Thomas, J.; Maes, M.; Robeyns, K.; Ovaere, M.; Van Meervelt, L.; Smet, M.; Dehaen, W. Org. Lett. 2009, 14, 3040. (b) Thomas, J.; Dobrzanska, L.; Van Hecke, K.; Sonawane, M. P.; Robeyns, K.; Van Meervelt, L.; Wozniak, K.; Smet, M.; Maes, W.; Dehaen, W. Org. Biomol. Chem. 2012, DOI: 10.1039/C2OB25760B.

(10) Maes, W.; Van Rossom, W.; Van Hecke, K.; Van Meervelt, L.; Dehaen, W. Org. Lett. 2006, 8, 4161.

(11) (a) Van Rossom, W.; Ovaere, M.; Van Meervelt, L.; Dehaen, W.; Maes, W. Org. Lett. 2009, 11, 1681. (b) Van Rossom, W.; Robeyns, K.; Ovaere, M.; Van Meervelt, L.; Dehaen, W.; Maes, W. Org. Lett. 2011, 13, 126.

(12) (a) Van Rossom, W.; Maes, W.; Dehaen, W. Org. Lett. 2008, 10, 585. (b) Van Rossom, W.; Kundrat, O.; Lhotak, P.; Maes, W.; Dehaen, W. Tetrahedron Lett. 2010, 51, 2423. (c) Van Rossom, W.; Caers, J.; Robeyns, K.; Van Meervelt, L.; Maes, W.; Dehaen, W. J. Org. Chem. 2012, 77, 2791.

(13) (a) von Angerer, S. In Science of Synthesis, Yamamoto, Y., Ed.; Georg Thieme Verlag: Stuttgart, 2004; Vol 16, p 379 and references therein. (b) Ruben, M.; Rojo, J.; Romero-Salguero, F. J.; Uppadine, L. H.; Lehn, J.-M. Angew.Chem., Int. Ed. 2004, 43, 3644.

(14) Bizier, N. P.; Vernamonti, J. P.; Katz, J. L. Eur. J. Org. Chem. 2012, 2303.

(15) Kajiwara, T.; Wu, H.; Ito, T.; Iki, N.; Miyano, S. Angew. Chem., Int. Ed. 2004, 43, 1832.

(16) (a) Parker, D.; Williams, J. A. G. J. Chem. Soc., Dalton Trans. 1996, 3613. (b) Caravan, P.; Ellison, J. J.; McMurry, T. J.; Lauffer, R. B. Chem. Rev. 1999, 99, 2293. (c) Hatscher, S. T.; Urland, W. Angew. Chem. 2003, 115, 2969.

(17) Gottlieb, H. E.; Kotlyar, V.; Nudelman, A. J. Org. Chem. 1997, $62,7512$.

(18) Tashiro, M.; Yamato, T. Org. Prep. Proced. Int. 1981, 13, 1.

(19) Sander, F.; Peterle, T.; Ballav, N.; Wrochem, F.; Zharnikov, M.; Mayor, M. J. Phys. Chem. 2010, 114, 4118.

(20) Kragulj, E. J.; Gustafson, J. L.; Grotjahn, D. B. Synlett 2007, 2851.

(21) Ashram, M.; Miller, D. O.; Bridson, J. N.; Georghiou, P. E. J. Org. Chem. 1997, 62, 6476.

(22) Nugent, R. A.; Schlachter, S. T.; Murphy, M. J.; Cleek, G. J.; Poel, T. J.; Wishka, D. G.; Graber, D. R.; Y. Yagi, Y.; Keiser, B. J.; Olmsted, R. A.; Kopta, L. A.; Swaney, S. M.; Poppe, S. M.; Morris, J.; Tarpley, W. G.; Thomas, R. C. J. Med. Chem. 1998, 41, 3793.

(23) Gupton, J. T.; Gall, J. E.; Riesinger, S. W.; Smith, S. Q.; Bevrit, K. M.; Sikorski, J. A.; Dahl, M. L.; Arnold, Z. J. Het. Chem. 1991, 28, 1281. 